\title{
Sexual Dimorphisms and Asymmetries of the Thalamo-Cortical Pathways and Subcortical Grey Matter of Term Born Healthy Neonates: An Investigation with Diffusion Tensor MRI
}

\author{
Fadoua Saadani-Makki ${ }^{1}$, Ardalan Aarabi ${ }^{2}{ }^{\mathbb{D}}$, Mahshid Fouladivanda $^{3}$, Karman Kazemi ${ }^{3}$ and Malek Makki ${ }^{2, *}$ \\ 1 PeriTox, UMR-I 01, INERIS, University of Picardy Jules Verne, 80037 Amiens, France; \\ fsaadani.makki@gmail.com \\ 2 Laboratory of Functional Neuroscience and Pathologies (LNFP), School of Medicine, \\ University of Picardy Jules Verne, 80037 Amiens, France; ardalan.aarabi@u-picardie.fr \\ 3 Department of Electrical and Electronics Engineering, Shiraz University of Technology, \\ Shiraz 71557-13876, Iran; m.fouladivanda@sutech.ac.ir (M.F.); kazemi@sutech.ac.ir (K.K.) \\ * Correspondence: malek.makki@gmail.com
}

Citation: Saadani-Makki, F.; Aarabi, A.; Fouladivanda, M.; Kazemi, K.; Makki, M. Sexual Dimorphisms and Asymmetries of the Thalamo-Cortical Pathways and Subcortical Grey Matter of Term Born Healthy Neonates: An Investigation with Diffusion Tensor MRI. Diagnostics 2021, 11, 560. https://doi.org/ 10.3390/diagnostics11030560

Academic Editor:

Panagiotis Papanagiotou

Received: 1 February 2021

Accepted: 18 March 2021

Published: 20 March 2021

Publisher's Note: MDPI stays neutral with regard to jurisdictional claims in published maps and institutional affiliations.

Copyright: (c) 2021 by the authors. Licensee MDPI, Basel, Switzerland. This article is an open access article distributed under the terms and conditions of the Creative Commons Attribution (CC BY) license (https:/ / creativecommons.org/licenses/by/ $4.0 /)$.

\begin{abstract}
Diffusion-tensor-MRI was performed on 28 term born neonates. For each hemisphere, we quantified separately the axial and the radial diffusion (AD, RD), the apparent diffusion coefficient (ADC) and the fractional anisotropy (FA) of the thalamo-cortical pathway (THC) and four structures: thalamus (TH), putamen (PT), caudate nucleus (CN) and globus-pallidus (GP). There was no significant difference between boys and girls in either the left or in the right hemispheric THC, TH, GP, $\mathrm{CN}$ and PT. In the combined group (boys + girls) significant left greater than right symmetry was observed in the THC (AD, RD and ADC), and TH (AD, ADC). Within the same group, we reported left greater than right asymmetry in the PT (FA), CN (RD and ADC). Different findings were recorded when we split the group of neonates by gender. Girls exhibited right $>$ left AD, RD and ADC in the THC and left $>$ right FA in the PT. In the group of boys, we observed right $>$ left RD and ADC. We also reported left $>$ right FA in the PT and left $>$ right RD in the $\mathrm{CN}$. These results provide insights into normal asymmetric development of sensory-motor networks within boys and girls.
\end{abstract}

Keywords: neonates; brain; DTI; putamen; caudate nucleus; globus pallidus; thalamus; thalamocortical pathway; asymmetry; boys; girls

\section{Introduction}

The thalamus and the basal ganglia (caudate, putamen and globus pallidus) are deep gray matter structures known to modulate motor, cognitive, and sensory functions $[1,2]$. However, the micro-structural changes of the subcortical regions differ across the thalamus $(\mathrm{TH})$, the caudate nucleus (CN), the putamen (PT) and the globus pallidus (GP) [3]. The maturation patterns of membrane proliferation [4] and fiber myelination [5] run in parallel to the brain circuit formation. These phenomena are intense in the developing deep grey matter of the neonate brain from 36 to 43 post menstrual weeks and result from regulated molecular and cellular processes [6]. Synapse formation [7], dendritic arborization [8], neurogenesis, neuronal migration, axonal growth and pruning [9] increase the brain size exponentially to reach $90 \%$ of adult volume around 2 years of age [10]. It has been reported that the whole-brain growth is about $1 \%$ per day, slowing to $0.4 \%$ / day by the end of the first 3 months [11]. The formation and the development of neural connections between the cerebral cortex and the thalamus require thalamo-cortical (THC) projections to synapse transiently in the temporary cortical subplate before penetrating the cortical plate [12]. Functional and structural MRI connectivity analysis between the TH and the cortex has described a parcellation of the $\mathrm{TH}$ with precise connectivity to specific cortical regions [13]. The thalamo-cortical fibers and the cortical dendritic tree are related to the development of synchronous cortical development in the last trimester when the 
subplate is at maximal extent $[14,15]$. At 24 weeks post-conception age, brain development is characterized by the migration of thalamo-cortical afferents from the subplate into the overlying cerebral cortex [16]. During this critical phase, any damage to these cell populations could impact the microstructural development of the subcortical gray matter and the cortex, thus disrupting the connective white matter fibers [17,18]. These connections form a set of parallel and segregated cortico-thalamic loops that project to the majority of the cortex and act as a link between the basal ganglia and cortex $[19,20]$. This allows the information flow to drive ascending integration of sensory information into higher-order cortical networks [21-23]. The thalamo-cortical network features widespread connectivity throughout the TH involving the primary sensory motor, temporal, medial prefrontal, anterior cingulate, and fronto-parietal insular cortices, and others are mainly limited to their areas of dominance (primary auditory, primary visual and lateral parietal) [12].

Any anatomical alterations underlying the subplate neurons, thalamic neurons and premyelinating oligodendrocytes that result from hypoxia/ischemia and infection/inflammation ultimately affect the corresponding neurological functions [24,25]. Several studies demonstrated that impaired cognition in premature infants is associated with impaired connectivity in the frontal-subcortical pathways including the THC networks leading to neurological disorders (attentional deficit/hyperactivity disorder (ADHD), autism spectrum disorders (ASD) and learning disabilities [21,26-30]. Many neonate studies provided evidence that during the second and third trimester, the brain undergoes substantial reorganization with exponential increases of the cortical volume and surface [31,32]. Diffusion MRI studies have shown that the microscopic tissue coherence decreases with the increases of anisotropy [22,33]. A histology study by Mrzljak et al. (1992) [34] demonstrated that this loss in cortical coherence corresponds to neuronal differentiation, dendritic arborization, and cortical axonal ingrowth. Previous studies on premature infants have reported asymmetric volumes in the perirhinal cortex [35], Brodmann area A44 [35,36], primary motor cortex [37], the middle temporal visual [38] and the language areas [39,40]. Studying the neonate brain is particularly challenging because the physiologic patterns change dramatically, the degree of plasticity is high, the structure sizes are too small, the WM/GM contrast is low, and there is motion of artifacts if sedation is not administrated. The plasticity and capacity for adaptation of the human brain offers considerable potential for optimizing brain outcomes through the development of early diagnostic tools and early interventions [41-43]. Noninvasive neuroimaging such as MRI is of utmost to study and monitor prenatal and postnatal brain development to improve diagnostic accuracy and to plan better guiding circuit-specific early interventions.

The aim of this study was to extend the previous work in lateralization of the corticospinal tracts [44] to provide insight into subcortical grey matter and THC pathways. Using DTI, we investigated whether 1) there are microstructural asymmetries in the CN, PT, GP, $\mathrm{TH}$ and THC pathways can be observed in neonates under 1 month of age and 2) whether there is a gender effect in these subcortical areas. For each structure, we assessed the sexual dimorphisms and left-right asymmetries for each DTI variable. Providing normative data to evaluate the white matter integrity in term born neonates will help in identifying abnormal brain development and pathological conditions.

\section{Materials and Methods}

\subsection{Subjects}

Thirty-five healthy term born neonates were recruited from the postnatal ward at our hospital and were examined with MRI. The subjects presented here were part of a prospective clinical trial investigating neonates with congenital heart disease undergoing transposition of the great artery. The institutional ethics committee approved this study, and written informed consent was obtained from guardians. The inclusion criteria are gestation age $>37$ weeks and normal Apgar score. Exclusion criteria are any congenital malformation or small for 37 weeks of gestation. Selected neonates were scanned in natural sleep and were monitored by pulse oximetry. Seven neonates were excluded either because 
of motion artefacts or they did not fall asleep to achieve the examination. Overall, DTI was successfully achieved on 28 infants (13 girls). A neonatal nurse was present during the examination to check the oxygen saturation, the arterial blood pressure, the heart rate and $\mathrm{P}_{\mathrm{CO}_{2}}$. Demographic details and age at scanning are listed in Table 1.

Table 1. Descriptive gestation age (GA) statistics of the neonates per group (W refers to number of week and D number of days).

\begin{tabular}{clllll}
\hline Gestation Age (GA) & N & Minimum & Maximum & Mean & Median \\
\hline Girls + Boys combined & 28 & $38 \mathrm{~W}+3 \mathrm{D}$ & $44 \mathrm{~W}+1 \mathrm{D}$ & $41 \mathrm{~W} \pm 6 \mathrm{D}$ & $42 \mathrm{~W}+0 \mathrm{D}$ \\
Girls & 13 & $38 \mathrm{~W}+3 \mathrm{D}$ & $43 \mathrm{~W}+3 \mathrm{D}$ & $41 \mathrm{~W} \pm 6 \mathrm{D}$ & $42 \mathrm{~W}+6 \mathrm{D}$ \\
Boys & 15 & $38 \mathrm{~W}+3 \mathrm{D}$ & $44 \mathrm{~W}+1 \mathrm{D}$ & $41 \mathrm{~W} \pm 6 \mathrm{D}$ & $42 \mathrm{~W}+0 \mathrm{D}$ \\
\hline
\end{tabular}

A routine clinical neuroimaging examination was performed on a 3-T scanner (GE Healthcare) with an eight-channel head coil. It included (i) isotropic 3D T1-weighted images utilizing a magnetization preparation fast spoiled gradient echo, (ii) sagittal 2D T2-weighted Fast-Spin-Echo, (iii) high-resolution morphologic axial $\mathrm{T}_{2} \mathrm{~W}$ fast spin echo, and (iv) diffusion-tensor spin-echo (DTI) echo planar sequence. The DTI was performed using 35 non-collinear gradient-diffusion directions and one volume of reference T2W images. The diffusion sensitivity gradient was set to $b$ value $700 \mathrm{sec} / \mathrm{mm}^{2}$. Imaging parameters are slice thickness $2.5 \mathrm{~mm}$ (between 34 and 38 slices covering the whole brain), FOV $220 \mathrm{~mm}^{2}$, matrix $128 \times 128$ homodyne reconstructed in $256 \times 256$ to achieve an in-plane resolution of $0.85 \times 0.85 \mathrm{~mm}^{2}$. Pulsed gradient double refocusing pulses were used to reduce eddy-current artifacts and parallel imaging $($ ASSET $\times 2)$ was applied. The acquisition time was $\sim 5 \min 30 \mathrm{~s}$.

\subsection{Image Acquisition and Analysis}

\subsubsection{Image Processing}

The thalamo-cortical fiber (THC) tracking was carried out with DTI Studio software (Department of Radiology, Johns Hopkins University, Baltimore, MD, USA) using the deterministic FACT algorithm (fiber assignment continuous tracking) and the following two rejection criteria: fractional anisotropy (FA) $<0.15$ or angulation $>70^{\circ}$. The seed regions were manually drawn on each axial slice of the TH on FA maps (4 to 5 slices). It has been applied with the inclusive "OR" operator. The target regions were selected FA maps at the coronal plane at the level of the genu. This was performed with an exclusive operator "AND". It was reproduced bilaterally to determine left and right THC pathways. The axial diffusion (AD), the radial diffusion (RD), the apparent diffusion coefficient (ADC) and the FA were measured and averaged separately over the entire left and the entire right THC. For each group (girls, boys and combined) we measured the DTI variables bilaterally on the selected four structures: TH, PT, GB, and CN (Figure 1).

For structure analysis, the delineation of each region was performed manually on each hemisphere. The regions of interest were carefully drawn covering the entire surface area on FA maps because the structure edges are well displayed and easily identified. An experienced scientist with over 10 years of practice carried out the ROI drawings. This procedure was repeated twice (one month apart) to minimize the subjectivity error. The results of the two measures were averaged to perform the statistical comparisons. The delineation was reproduced on axial planes and going through the entire structure. We calculated the DTI variables (AD, RD, ADC and FA) by averaging the measured values. For each of the 4 DTI variables, we calculated the asymmetry index (AI) to identify the dominance hemisphere per structure and gender. Dominance was attributed to the left side if AI value is positive and to the right if it is negative.

$$
A I=\frac{2 \cdot(L-R)}{(L+R)} \%
$$




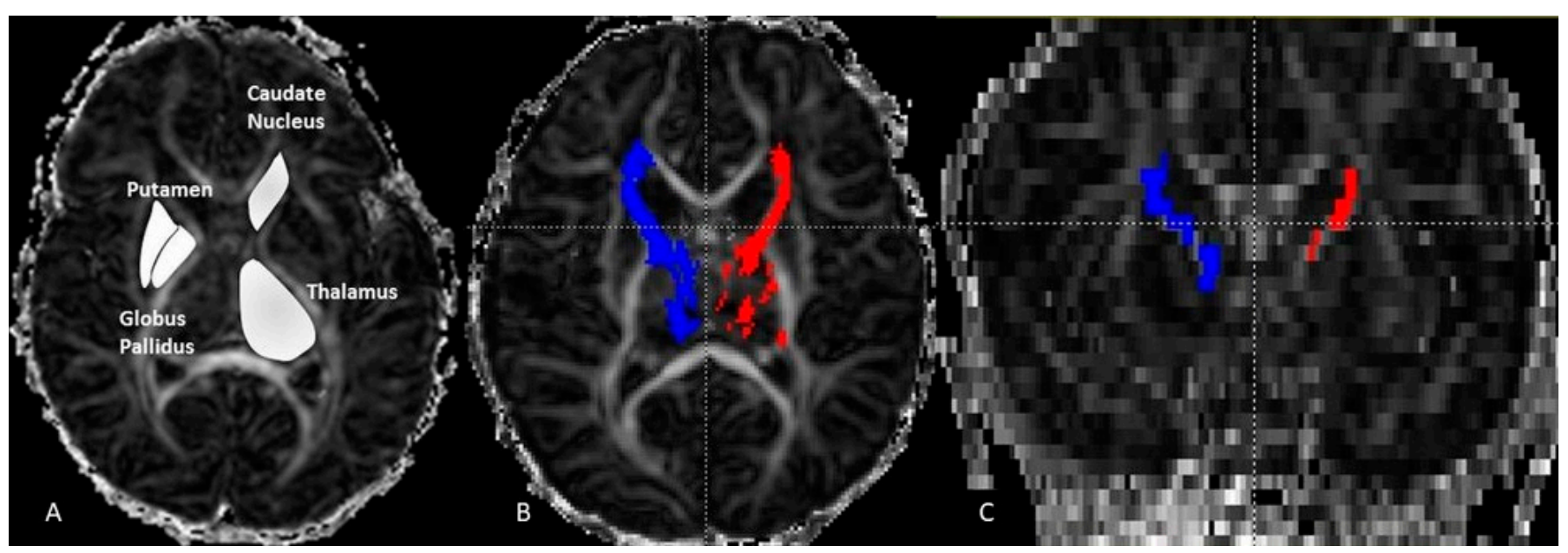

Figure 1. Axial fractional anisotropy (FA) image (A) displaying the ROI manual drawing on the thalamus, caudate-nucleus, putamen and globus pallidus. On the (B) image the result of fiber tracking of the left (red) and right (blue) thalamocortical pathways. The same pathways are displayed in the coronal plane $(\mathbf{C})$. These were performed on a neonate girl ( $\mathrm{GA}=43$ weeks +3 days)

\subsubsection{Statistical Data Analysis}

The statistical analyses were performed with SPSS (Statistical Package for the Social Sciences, Version 22.0). The inter-group differences (Girls vs. Boys) were tested separately for the 5 structures (TH, PT, GP, CN and THC) on both sides (left and right). This test was repeated for each DTI index using a general linear model multiple analysis of covariance with $p<0.05$ were considered significant. Postconceptional age at MR imaging of the subjects was included as a covariate to control for age-related changes of DTI indices. Following Bonferroni correction for type I error ( 5 structures $\times 2$ sides $\times 2$ groups $=20$ tests), group differences with $p<0.002$ were considered significant.

The intra-group statistical comparison between left and right was performed separately for each structure (TH, PT, GP, CN and THC) and each group (girls, boys and combined) with paired $t$-Test. The significance was set to $p<0.05$.

\section{Results}

\subsection{Left-Right Asymmetry Girls and Boys Combined}

Left and right comparisons of the combined group (girls and boys) demonstrated significantly higher axial diffusion $(p=0.009)$ and $\operatorname{ADC}(p=0.023)$ in the right thalamus compared to the left (Figure 2A). The PT has significantly higher FA in the left $(p=0.015)$ compared to the right. No asymmetry was reported in the globus pallidus (Table 2). The right THC pathway exhibited significantly larger axial diffusion $(p=0.003)$, radial diffusion $(p=0003)$ and ADC $(p=0.001)$ compared to the left (Figure 3A). The left caudate nucleus had higher radial diffusion $(p=0.049)$ and higher ADC $(p=0.040)$ compared to the right (Figure 4A).

\subsection{Left-Right Asymmetry in the Girl Group}

The thalamus of the girl group had significantly higher axial diffusion in the right ( $p=0.048)$ compared to the left (Figure 2B) and the right THC pathway presented with significantly higher axial diffusion $(p=0.004)$, radial diffusion $(p=0.010)$ and $\operatorname{ADC}(p=0.001)$ (Figure 3B). The FA of the left PT was significantly higher $(p=0.015)$ than the right. The $\mathrm{CN}$ and the GP did not reveal any significant asymmetry (Table 3). 
Table 2. Paired $t$-Test of the combined group (Girls + Boys). This was performed to compare left and right values of the axial diffusion (AD), radial diffusion (RD), apparent diffusion coefficient (ADC) and fractional anisotropy (FA). The comparison was carried out on the thalamo-cortical pathways, the thalamus, caudate-nucleus, globus pallidus and putamen. ${ }^{*}$ The difference was set to be significant when it was below 0.05 .

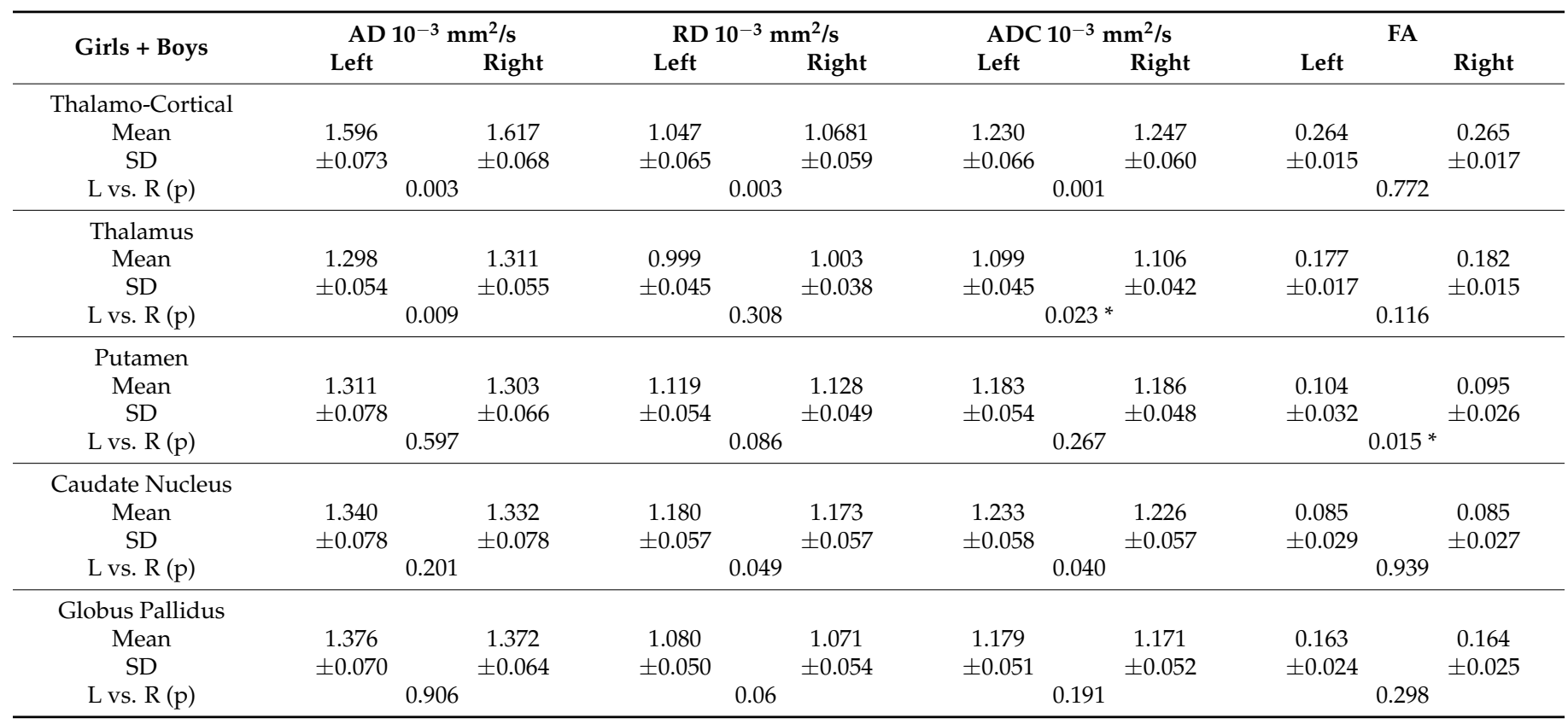

Table 3. Paired $t$-Test of the two separate groups by gender Girls. The test was performed to compare left and right values of the axial diffusion (AD), radial diffusion (RD), apparent diffusion coefficient (ADC) and fractional anisotropy (FA). The comparison was carried out on the thalamo-cortical pathways, the thalamus, caudate-nucleus, globus pallidus and putamen. The difference was set to be significant when it was below 0.05 .

\begin{tabular}{|c|c|c|c|c|c|c|c|c|c|c|c|c|c|}
\hline \multirow{2}{*}{ Paired $t$-Test } & & \multicolumn{2}{|c|}{$\mathrm{AD} 10^{-3} \mathrm{~mm}^{2} / \mathrm{s}$} & \multicolumn{4}{|c|}{$\mathrm{RD} 10^{-3} \mathrm{~mm}^{2} / \mathrm{s}$} & \multicolumn{3}{|c|}{$\operatorname{ADC} 10^{-3} \mathrm{~mm}^{2} / \mathrm{s}$} & \multirow{2}{*}{$\begin{array}{l}\text { FA } \\
\text { Left }\end{array}$} & \multirow[b]{2}{*}{ Right } & \multirow[b]{2}{*}{$p$} \\
\hline & & Left & Right & $p$ & Left & Right & $p$ & Left & Right & $p$ & & & \\
\hline \multicolumn{14}{|l|}{ Girls } \\
\hline \multirow{2}{*}{$\mathrm{TH}-\mathrm{C}$} & $\mathrm{M}$ & 1.579 & 1.601 & 0.004 & 1.032 & 1.047 & 0.010 & 1.215 & 1.232 & 0.001 & 0.266 & 0.267 & 0.821 \\
\hline & SD & 0.037 & 0.039 & & 0.035 & 0.036 & & 0.034 & 0.031 & & 0.136 & 0.019 & \\
\hline \multirow{2}{*}{ TH } & $\mathrm{M}$ & 1.300 & 1.311 & 0.04 & 0.999 & 1.001 & 0.820 & 1.099 & 1.104 & 0.430 & 0.179 & 0.185 & 0.068 \\
\hline & SD & 0.096 & 0.046 & & 0.035 & 0.036 & & 0.036 & 0.029 & & 0.012 & 0.015 & \\
\hline \multirow{2}{*}{ PT } & $\mathrm{M}$ & 1.296 & 1.292 & 0.597 & 1.114 & 1.128 & 0.086 & 1.175 & 1.182 & 0.267 & 0.100 & 0.089 & 0.015 \\
\hline & SD & 0.041 & 0.028 & & 0.039 & 0.035 & & 0.035 & 0.031 & & 0.021 & 0.013 & \\
\hline \multirow[b]{2}{*}{$\mathrm{CN}$} & $\mathrm{M}$ & 1.338 & 1.322 & 0.090 & 1.171 & 1.166 & 0.539 & 1.226 & 1.218 & 0.223 & 0.089 & 0.084 & 0.134 \\
\hline & SD & 0.047 & 0.036 & & 0.034 & 0.039 & & 0.032 & 0.033 & & 0.023 & 0.020 & \\
\hline \multirow{2}{*}{ GP } & $\mathrm{M}$ & 1.358 & 1.359 & 0.906 & 1.068 & 1.056 & 0.067 & 1.165 & 1.157 & 0.191 & 0.162 & 0.167 & 0.298 \\
\hline & SD & 0.036 & 0.035 & & 0.031 & 0.036 & & 0.029 & 0.032 & & 0.017 & 0.019 & \\
\hline
\end{tabular}

\subsection{Left-Right Asymmetry in the Boy Group}

Significantly higher radial diffusion $(p=0.047)$ and ADC $(p=0.005)$ were recorded in the right compared to the left TH (Figure $2 \mathrm{C}$ ) in the boys group (Table 4 ). The FA of the left PT was significantly higher $(p=0.044)$ than the right (Figure 5$)$. The caudate nucleus showed significantly higher ADC in the right $(p=0.043)$ compared to the left (Figure $4 \mathrm{~B})$. The GP did not reveal any significant asymmetry. 
Table 4. Paired $t$-Test of the two separate groups by gender Girls and Boys. The test was performed to compare left and right values of the axial diffusion (AD), radial diffusion (RD), apparent diffusion coefficient (ADC) and fractional anisotropy (FA). The comparison was carried out on the thalamo-cortical pathways, the thalamus, caudate-nucleus, globus pallidus and putamen. ${ }^{*}$ The difference was set to be significant when it was below 0.05 .

\begin{tabular}{|c|c|c|c|c|c|c|c|c|c|c|c|c|c|}
\hline \multirow{2}{*}{$\begin{array}{c}\text { Paired } \\
t \text {-Test }\end{array}$} & & \multicolumn{2}{|c|}{$\operatorname{AD~} 10^{-3} \mathrm{~mm}^{2} / \mathrm{s}$} & \multicolumn{4}{|c|}{$\mathrm{RD} 10^{-3} \mathrm{~mm}^{2} / \mathrm{s}$} & \multicolumn{3}{|c|}{ ADC $10^{-3} \mathrm{~mm}^{2} / \mathrm{s}$} & \multirow{2}{*}{$\begin{array}{c}\text { FA } \\
\text { Left }\end{array}$} & \multirow[b]{2}{*}{ Right } & \multirow[b]{2}{*}{$p$} \\
\hline & & Left & Right & $p$ & Left & Right & $p$ & Left & Right & $p$ & & & \\
\hline \multicolumn{14}{|l|}{ Boys } \\
\hline \multirow{2}{*}{ THC } & $\mathrm{M}$ & 1.061 & 1.632 & \multirow[t]{2}{*}{0.085} & 1.060 & 1.074 & \multirow[t]{2}{*}{0.083} & 1.244 & 1.260 & \multirow[t]{2}{*}{0.070} & 0.262 & 0.263 & \multirow[t]{2}{*}{0.862} \\
\hline & SD & 0.095 & 0.086 & & 0.083 & 0.074 & & 0.086 & 0.077 & & 0.017 & 0.016 & \\
\hline \multirow{2}{*}{$\mathrm{TH}$} & $\mathrm{M}$ & 1.297 & 1.312 & \multirow[t]{2}{*}{0.081} & 1.002 & 1.006 & \multirow[t]{2}{*}{0.047} & 1.100 & 1.108 & \multirow[t]{2}{*}{0.005} & 0.175 & 0.180 & \multirow[t]{2}{*}{0.3345} \\
\hline & SD & 0.062 & 0.032 & & 0.052 & 0.047 & & 0.052 & 0.050 & & 0.020 & 0.015 & \\
\hline \multirow{2}{*}{$\mathrm{PT}$} & $\mathrm{M}$ & 1.324 & 1.313 & \multirow[t]{2}{*}{0.338} & 1.124 & 1.128 & \multirow[t]{2}{*}{0.662} & 1.191 & 1.189 & \multirow[t]{2}{*}{0.864} & 0.107 & 0.099 & \multirow[t]{2}{*}{0.044} \\
\hline & SD & 0.100 & 0.087 & & 0.066 & 0.059 & & 0.066 & 0.059 & & 0.039 & 0.034 & \\
\hline \multirow{2}{*}{$\mathrm{CN}$} & $\mathrm{M}$ & 1.342 & 1.340 & \multirow[t]{2}{*}{0.801} & 1.188 & 1.177 & \multirow[t]{2}{*}{$0.043 *$} & 1.240 & 1.232 & \multirow[t]{2}{*}{0.079} & 0.080 & 0.086 & \multirow[t]{2}{*}{0.279} \\
\hline & $\mathrm{SD}$ & 0.096 & 0.099 & & 0.070 & 0.067 & & 0.072 & 0.071 & & 0.032 & 0.032 & \\
\hline \multirow{2}{*}{ GP } & $\mathrm{M}$ & 1.392 & 1.393 & \multirow[t]{2}{*}{0.392} & 1.090 & 1.084 & \multirow[t]{2}{*}{0.351} & 1.190 & 1.184 & \multirow[t]{2}{*}{0.287} & 0.165 & 0.162 & \multirow[t]{2}{*}{0.443} \\
\hline & SD & 0.087 & 0.080 & & 0.061 & 0.064 & & 0.063 & 0.063 & & 0.028 & 0.029 & \\
\hline
\end{tabular}

\subsection{Hemispheric Dominance by Group}

Overall, the combined group and the boy group had right dominance of the thalamic $\mathrm{RD}$, but the girl group showed a left dominance. The dominances of the AD, ADC and FA were all to the right. In the THC, the right dominance was the same for all groups and each DTI variable. In the PT, the AD dominance was to the left in the combined group and among girls, but it was to the right side among boys. We observed the opposite trend in $\mathrm{ADC}$, where the dominance was to the right for girls and the combined group and to the right among the boys. In addition, the dominance of ADC was to the right while the FA dominance was to the left (Table 5).

Table 5. Asymmetry index (AI) between left and right of the selected structures and pathway. It was calculated for each index (AD axial diffusion, RD radial diffusion, ADC apparent diffusion coefficient and FA fractional anisotropy) and group (girls, boys, combined). The letter in parenthesis indicates the dominant side (left L, right R).

\begin{tabular}{|c|c|c|c|c|c|}
\hline \multicolumn{2}{|c|}{ AI \% } & $\mathrm{AD}$ & RD & ADC & FA \\
\hline \multirow{3}{*}{ Thalamo-cortical } & Girls & $-1.37 \pm 1.42(\mathbf{R})$ & $-1.45 \pm 1.79(\mathbf{R})$ & $-1.43 \pm 1.26(\mathbf{R})$ & $-0.20 \pm 4.03(\mathbf{R})$ \\
\hline & Boys & $-1.23 \pm 2.73(\mathbf{R})$ & $-1.23 \pm 2.88(\mathbf{R})$ & $-1.22 \pm 2.63(\mathbf{R})$ & $-0.38 \pm 4.53(\mathbf{R})$ \\
\hline & Combined & $-1.37 \pm 2.12(\mathbf{R})$ & $-1.41 \pm 2.27(\mathbf{R})$ & $-1.40 \pm 1.91(\mathbf{R})$ & $-0.18 \pm 3.88(\mathbf{R})$ \\
\hline \multirow{3}{*}{ Thalamus } & Girls & $-1.12 \pm 2.02(\mathbf{R})$ & $0.06 \pm 2.44(\mathbf{L})$ & $-0.40 \pm 1.73(\mathbf{R})$ & $-4.40 \pm 9.26(\mathbf{R})$ \\
\hline & Boys & $-0.85 \pm 1.76(\mathbf{R})$ & $-0.93 \pm 1.63(\mathbf{R})$ & $-0.89 \pm 1.05(\mathbf{R})$ & $-1.37 \pm 8.66(\mathbf{R})$ \\
\hline & Combined & $-0.97 \pm 1.89(\mathbf{R})$ & $-0.48 \pm 2.11(\mathbf{R})$ & $-0.67 \pm 1.43(\mathbf{R})$ & $-2.73 \pm 9.07(\mathbf{R})$ \\
\hline \multirow{3}{*}{ Putamen } & Girls & $0.06 \pm 2.04(\mathbf{L})$ & $-1.50 \pm 2.18(\mathbf{R})$ & $-0.92 \pm 1.84(\mathbf{R})$ & $10.14 \pm 12.78(\mathrm{~L})$ \\
\hline & Boys & $0.76 \pm 3.37(\mathbf{L})$ & $-0.35 \pm 2.44(\mathbf{R})$ & $0.076 \pm 2.46(\mathrm{~L})$ & $7.36 \pm 13.56(\mathrm{~L})$ \\
\hline & Combined & $0.54 \pm 2.82(\mathbf{L})$ & $-0.75 \pm 2.38(\mathbf{R})$ & $-0.27 \pm 2.25(\mathbf{R})$ & $8.52 \pm 12.80(\mathbf{L})$ \\
\hline \multirow{3}{*}{ Caudate Nucleus } & Girls & $1.01 \pm 2.40(\mathbf{L})$ & $0.30 \pm 0.02(\mathbf{L})$ & $0.56 \pm 1.69(\mathbf{L})$ & $4.87 \pm 16.08(\mathrm{~L})$ \\
\hline & Boys & $0.16 \pm 2.09(\mathbf{L})$ & $0.90 \pm 1.56(\mathbf{L})$ & $0.63 \pm 1.27(\mathbf{L})$ & $-5.84 \pm 20.67(\mathbf{R})$ \\
\hline & Combined & $0.56 \pm 2.24(\mathbf{L})$ & $0.61 \pm 1.58(\mathbf{L})$ & $0.59 \pm 1.45(\mathbf{L})$ & $-0.87 \pm 19.13(\mathbf{R})$ \\
\hline \multirow{3}{*}{ Globus Pallidus } & Girls & $-0.38 \pm 2.30(\mathbf{R})$ & $0.99 \pm 2.09(\mathbf{L})$ & $0.45 \pm 1.65(\mathbf{L})$ & $-3.79 \pm 10.87(\mathbf{R})$ \\
\hline & Boys & $0.82 \pm 2.87(\mathbf{L})$ & $0.55 \pm 2.13(\mathrm{~L})$ & $0.66 \pm 2.00(\mathbf{L})$ & $1.62 \pm 9.22(\mathrm{~L})$ \\
\hline & Combined & $0.27 \pm 2.57(\mathbf{L})$ & $0.84 \pm 2.08(\mathbf{L})$ & $0.62 \pm 1.84(\mathbf{L})$ & $-0.59 \pm 9.66(\mathbf{R})$ \\
\hline
\end{tabular}

In the $\mathrm{CN}$ we observed left dominance in $\mathrm{AD}, \mathrm{RD}$ and $\mathrm{ADC}$ among girls and boys and in the combined group. The FA of the $\mathrm{CN}$ was left dominant among girls and right dominant among boys and the combined group.

The GB dominance side was in the left for RD and ADC in all three groups. For AD the dominance was to the right for girls and to the left for boys and the combined group. 
The FA was dominant in the right for girls, to the left for boys and to the right for the combined group.

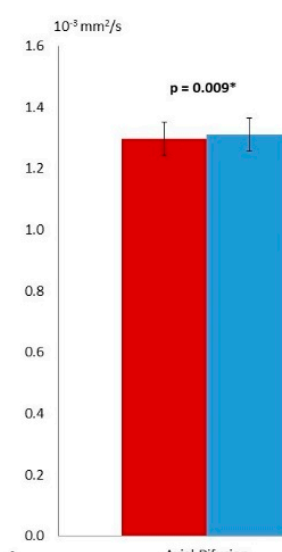

Axial Difusion

Thalamus: Girls and boys combined
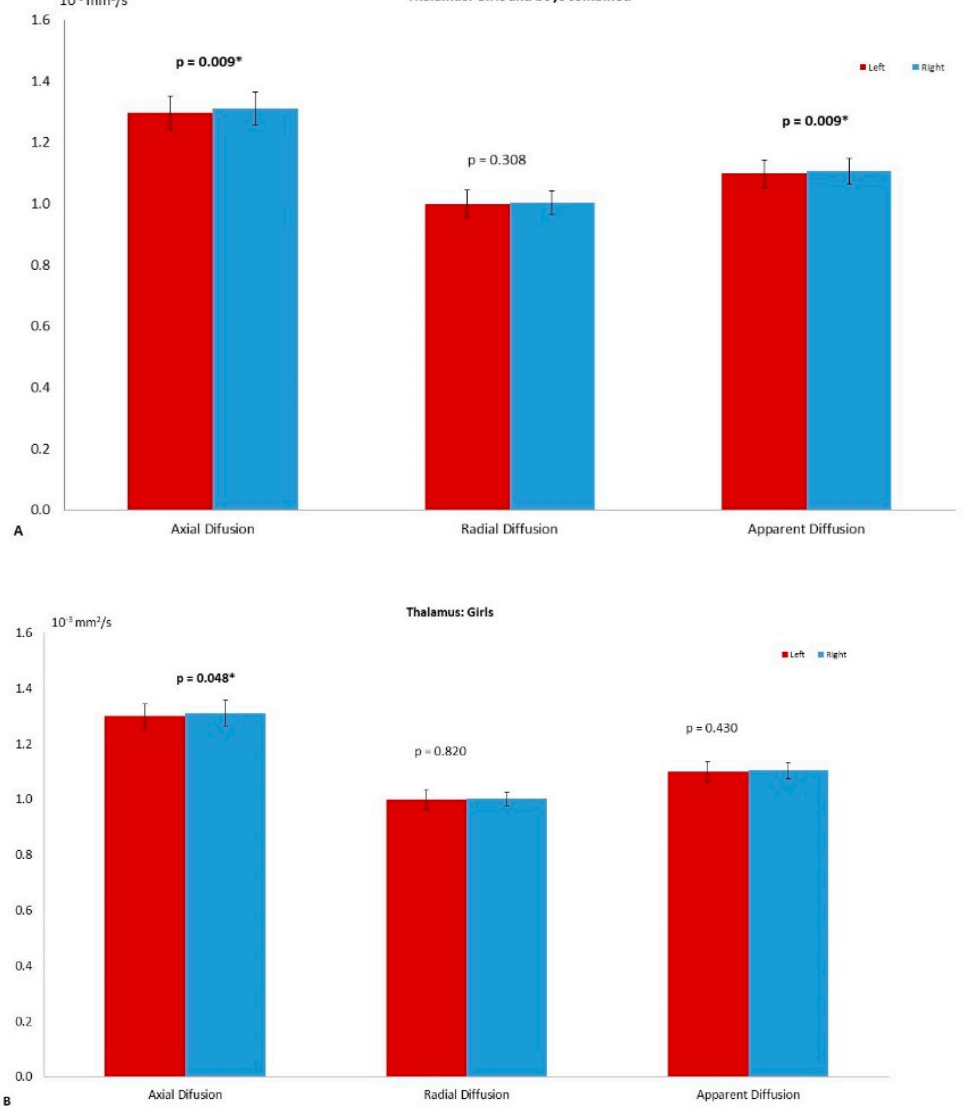

Radial Diffusion

Apparent Diffusion

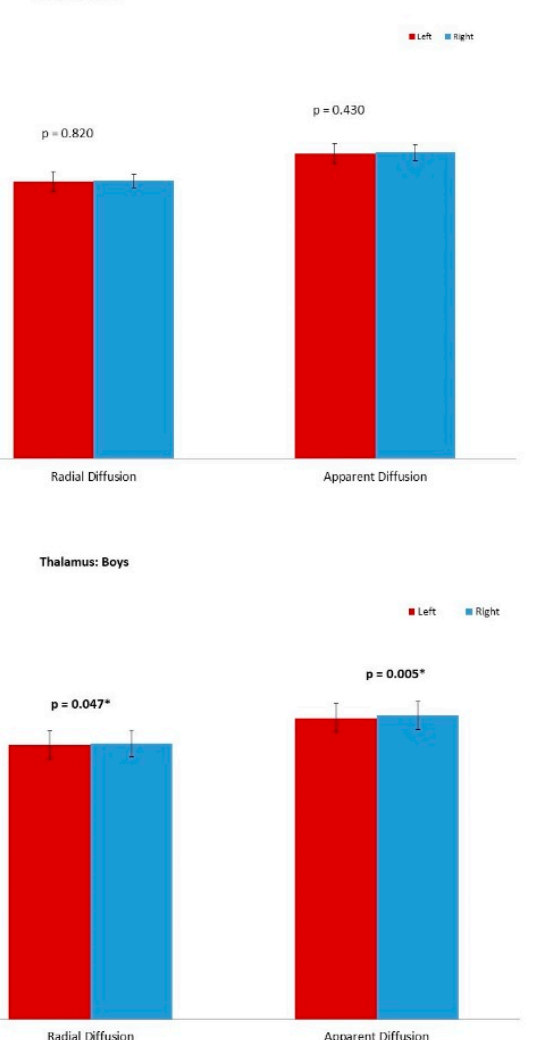

Figure 2. The left-right asymmetry of the thalamus. (A) The differences on axial diffusion (AD $p=0.009$ ), radial diffusion (RD) and apparent diffusion coefficient (ADC, $p=0.023$ ) in the combined group (girls and boys). The star $\left(^{*}\right)$ refers to significant difference. On (B) the asymmetry observed in the girl group with $\mathrm{AD}(p=0.048), \mathrm{RD}$ and ADC. The graph on $(\mathbf{C})$ shows the differences for the boy group $\mathrm{AD}, \operatorname{RD}(p=0.047)$ and $\operatorname{ADC}(p=0.005)$. The significance was set to $p=0.05$. 


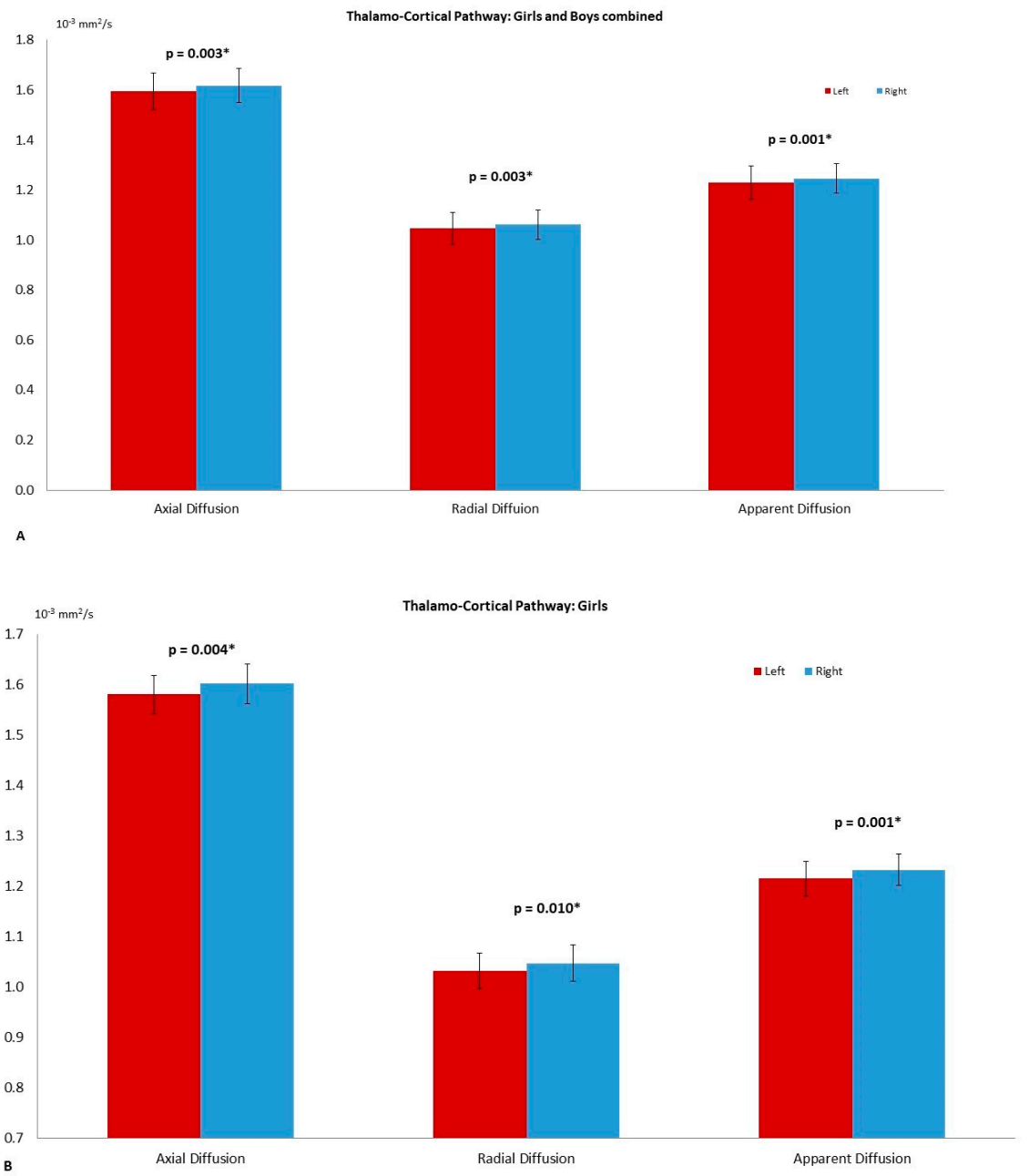

Figure 3. The asymmetry observed in the thalamo-cortical pathway with the axial diffusion (AD, $p=0.003$ ); radial diffusion (RD, $p=0.003$ ) and apparent diffusion coefficient (ADC, $p=0.001$ ) of the combined group (A). On (B) the differences among girls $\operatorname{AD}(p=0.004), \operatorname{RD}(p=0.010)$ and ADC $(p=0.001)$. The significance was set to $p=0.05$ and highlighted with a star superscript $\left(^{*}\right)$.

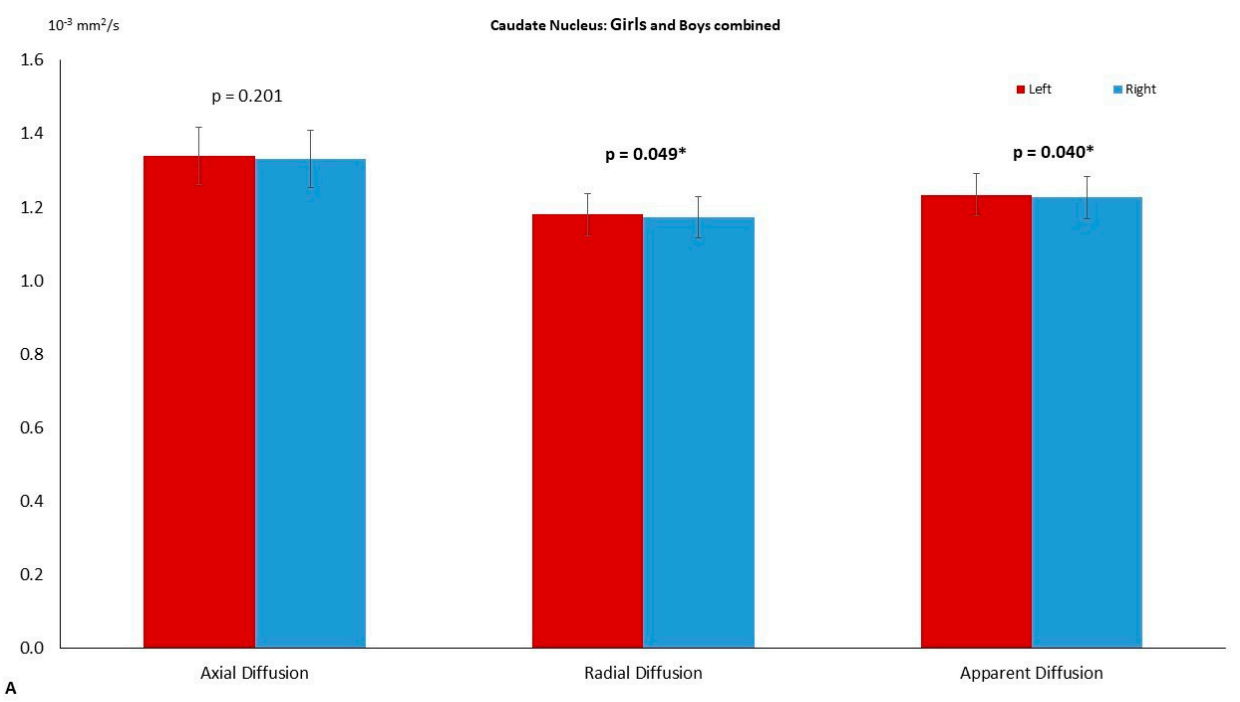

Figure 4. Cont. 


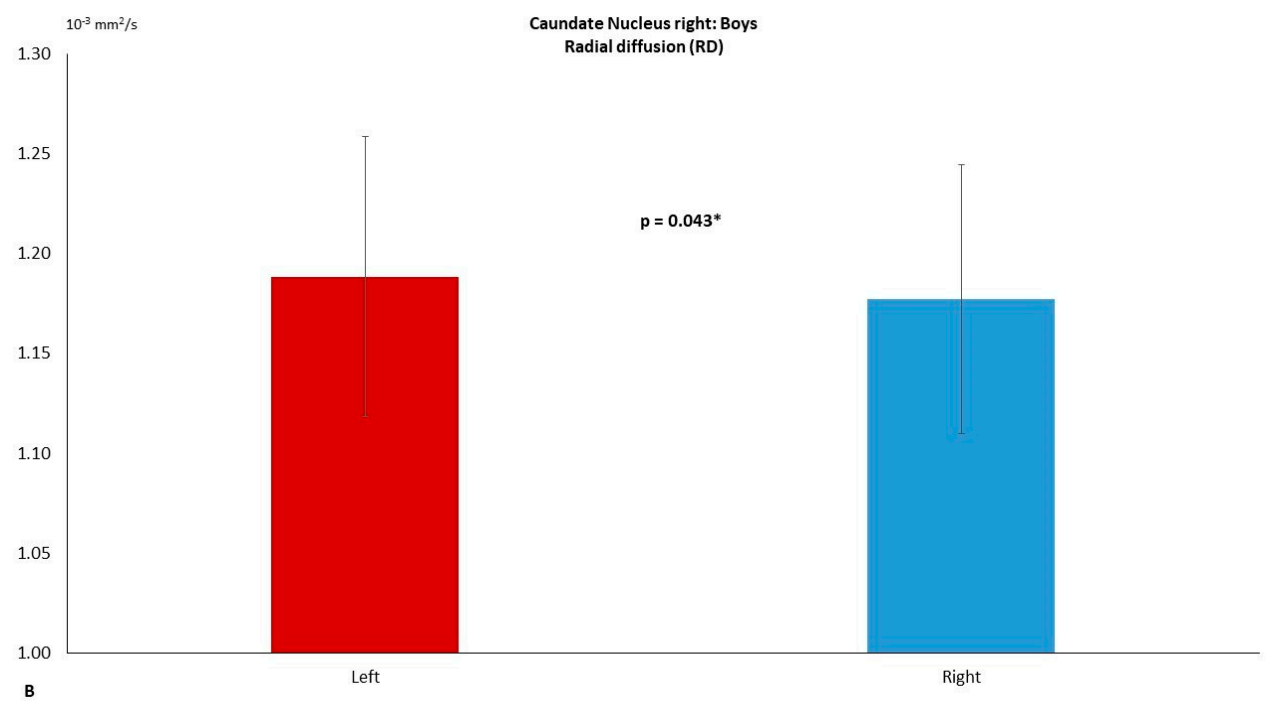

Figure 4. The left-right asymmetry of the caudate-nucleus. (A) The differences on axial diffusion (AD), radial diffusion (RD, $p=0.049$ ) and apparent diffusion coefficient (ADC, $p=0.040$ ) in the combined group (girls and boys). On (B) the asymmetry observed in the boy group with RD $(p=0.043)$. The significance was set to $p=0.05$ and highlighted with a star superscript $\left(^{*}\right)$.

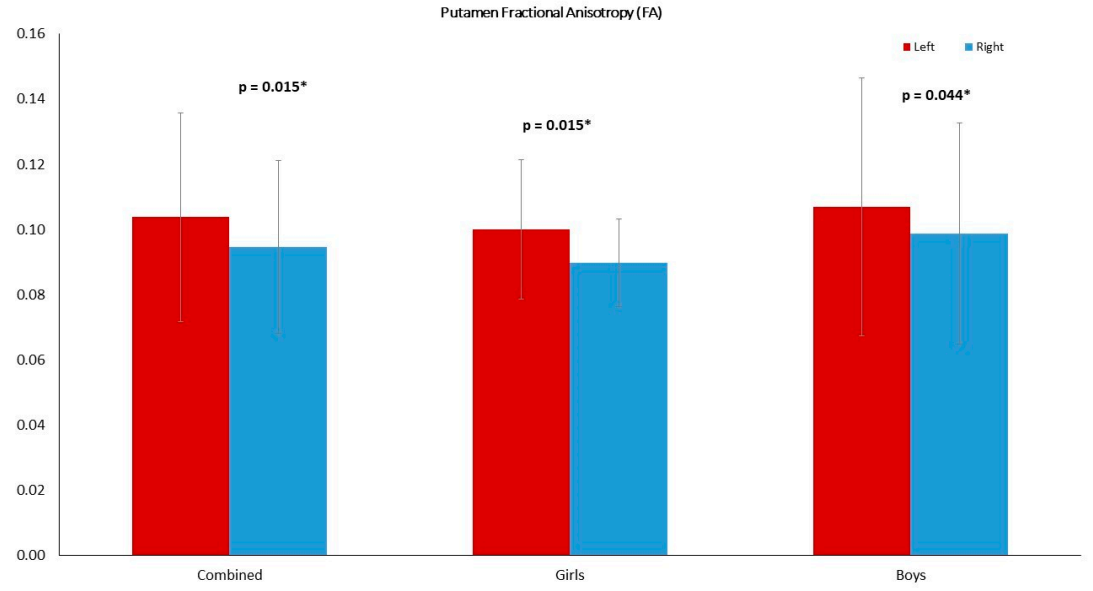

Figure 5. The putamen FA was higher in the left compared to the right in all groups: girls and boys combined $(p=0.015)$, girls $(p=0.015)$ and boys $(p=0.044)$. The significance was set to $p=0.05$. and highlighted with a star superscript $\left(^{*}\right)$.

\subsection{Gender Dimorphism}

The GLM analysis of covariance of the DTI variables revealed that there was no significant difference between boys and girls in any of the structures (Table 6). No gender dimorphism was observed in the left or in the right side. 
Table 6. Inter-group differences Girls vs. Boys were carried out separately for the five structures using a general linear model analysis of covariance with gestation age at MRI as the covariate. The test was performed bilaterally to compare the values of the axial diffusion (AD), radial diffusion (RD), apparent diffusion coefficient (ADC) and fractional anisotropy (FA). The difference was set to be significant when it was below 0.002 .

\begin{tabular}{|c|c|c|c|c|c|c|c|c|}
\hline \multirow{2}{*}{$\begin{array}{l}\text { General Linear Model - } \\
\text { Analysis of Covariance }\end{array}$} & \multicolumn{2}{|c|}{ AD $10^{-3} \mathrm{~mm}^{2} / \mathrm{s}$} & \multicolumn{2}{|c|}{$\mathrm{RD} 10^{-3} \mathrm{~mm}^{2} / \mathrm{s}$} & \multicolumn{2}{|c|}{$\operatorname{ADC} 10^{-3} \mathrm{~mm}^{2} / \mathrm{s}$} & \multirow{2}{*}{$\begin{array}{l}\text { FA } \\
\text { Left }\end{array}$} & \multirow[b]{2}{*}{ Right } \\
\hline & Left & Right & Left & Right & Left & Right & & \\
\hline \multicolumn{9}{|l|}{ Girls vs. Boys } \\
\hline Thalamo-cortical & 0.297 & 0.255 & 0.270 & 0.245 & 0.271 & 0.231 & 0.497 & 0.536 \\
\hline Thalamus & 0.950 & 0.803 & 0.851 & 0.597 & 0.881 & 0.832 & 0.789 & 0.130 \\
\hline Putamen & 0.351 & 0.401 & 0.639 & 0.990 & 0.440 & 0.702 & 0.584 & 0.376 \\
\hline Caudate Nucleus & 0.720 & 0.440 & 0.415 & 0.632 & 0.481 & 0.506 & 0.615 & 0.695 \\
\hline Globus-Pallidus & 0.207 & 0.324 & 0.269 & 0.166 & 0.191 & 0.174 & 0.763 & 0.556 \\
\hline
\end{tabular}

\section{Discussion}

This study on the neonate brain aimed to answer two questions regarding the thalamus, basal ganglia and the thalamo-cortical connectivity. The first involved the gender effect on their cyto-architecture. In fact, we did not observe any sexual dimorphism with regard to DTI variables neither in the left nor in the right side of these structures and the THC pathways. The second question was about left-right asymmetry in these parts of deep grey matter. Our results showed different findings by side, gender, structure and index. There was right ward asymmetry in all DTI indices (right $>$ left) in the thalamo-cortical pathways of boys, girls and the combined group. We measured also right ward asymmetry in all DTI metrics in the thalamus of the combined group, boys, and girls but the RD of the latest. In the putamen, there was left asymmetry in the AD and FA, and right asymmetry in the RD of the three groups. The ADC exhibited different asymmetry: Left among boys, right among girls and the combined group. The caudate nucleus asymmetry was exclusively to the left among girls. The combined group and the boy group had left asymmetry in AD, RD and ADC but right asymmetry FA. In the globus-pallidus, the boy group had left asymmetry in all DTI indices while girls had right asymmetry in AD and FA, but left asymmetry in RD and AD. The combined group exhibited left asymmetry in AD, RD and ADC but right asymmetry in FA.

In full-term neonates GA, birth weight, crown-heel length and head circumference affect WM maturation and it has been demonstrated that there is a biological link between the DTI indices (FA, ADC, AD and RD) and brain WM microstructural integrity, water diffusivities, axonal growth and myelination $[45,46]$. The thalamus and the basalganglia experience significant and continuous changes with age and they all reach the $90 \%$ mark between the ages of 21 and 24 years [47]. In our study, the patterns of cerebral asymmetry of the selected brain structures are different from those observed in other structures, suggesting that neonate patterns of cerebral asymmetry after birth are not homogeneous and might change until they reach the milestone mark. Cerebral asymmetry has been associated with lateralization including handedness, dexterity, and language abilities [48]. Several neurological disorders are believed to be developmental and are associated with atypical brain asymmetry [49], particularly schizophrenia [50], autism [51], Tourette syndrome [52] and Sturge-Weber syndrome [53]. The anatomical and functional asymmetries in the brain are thought to arise from asymmetric gene expression in the embryonic human cortex $[54,55]$, and can be observed in the human embryonic cortex around 12 weeks [54]. Previous investigations observed left greater than right lateral ventricles in the fetus brain [56] hemisphere about 20-22 weeks gestational age [57], and neonatal volumetric cortical white matter [58]. Other studies on children and adults reported right greater than left hemisphere $[10,39,59]$. Neonates with early deviant brain asymmetry who are at risk for a neurodevelopmental disorder may influence the pattern of asymmetry reported on children and adolescents because it is likely an early environmental insult to the developing brain. Puetz VB et al. (2017) [60] suggested that postnatal stress disorder with 
loss of normal frontal lobe asymmetry may influence the development of adult patterns of asymmetry.

Previous neuroimaging investigation of the potential neuroanatomical substrates of cognitive impairment from various causes supported the involvement of the thalamus in the network responsible for cognitive performance [61]. The thalamus serves as a relay station for all cortical sensory systems and plays a critical and a central role in the development of cortical circuitry and multisensory and sensorimotor functions and an isolated damage of the thalamus may result in cognitive dysfunction. Bültmann et al. (2017) [62] demonstrated that the TH structure has high concentration of myelin-associated macromolecules and a low water content, low diffusivities, and low coherence. The interconnections between the TH and PT have been demonstrated to belong to the motor circuit [63,64], and the oculomotor circuits including the dorsolateral prefrontal subcortical circuit (DLPC), the lateral orbitofrontal-subcortical circuit (LOFC). The vulnerability between the TH and PT related to preterm birth has been demonstrated by the scale and the translation of the left PT with that of the left TH while the right TH and PT are significantly associated through rotation $[65,66]$. The TH significantly right greater than left $\mathrm{AD}$ and $\mathrm{ADC}$ in the combined group, $\mathrm{RD}$ and $\mathrm{ADC}$ among boys, and $\mathrm{AD}$ among girls are in line with these interactions.

With regards to the caudate, it has been shown that the left is larger than the right, while the right hippocampus, thalamus, putamen and cerebellum were larger than the left $[11,35,67]$. Koolschijn and Crone (2013) have found statistically significant shifts toward increased volumetric and surface area measurements among males relative to females in line with previous findings [68]. In our study, left larger than right $\mathrm{RD}$ were observed in the combined group and among boys. The left ADC was larger than the right in the combined group as well. Hypoxic-ischaemic injury studies have documented atrophy of basal ganglia structures [69] and thalamus [70]. Voxel-based morphometry confirmed that hypoxic ischaemic patients showed bilateral volume reduction in the thalamus and the caudate nucleus [71]. Alcauter et al. (2017) study on neonates identified the development of the thalamo-sensorimotor and the thalamo-salience network connectivity as the only higherorder network that can be tracked before 1 year of age and an alteration of the thalamiccortical connectivity was associated to cognitive impairment in premature newborns [72].

During the neonate period, changes in DTI metrics correlate with any of the following phenomena: increase in myelin sheaths, increments of axon density, cell membrane, and glial cells [46]. The globus-pallidus reflects development of postural balance. However, Cahill-Rowley et al. (2019) did not report a significant correlation between the DTI metrics of the globus pallidus and both walking velocity and single limb support [73]. The lack of significant asymmetry observed in the globus-pallidus may presumably relate to slow development of sensorimotor ability. This feature might change with age and the neurodevelopmental process but given the complexity in brain development and the environmental relationship, further investigation is needed to explain the physiological and neurological processes as deep gray matter structures show very large percent changes and the white matter structures showing smaller, but still significant, changes [45].

Around $26 \mathrm{GW}$ the fetal brain development is characterized by the establishment of structural THC axons from the cortical plate to subplate $[9,74]$ and the beginning of massive cortical synaptogenesis, which marks the first step towards the beginning of sensory driven activity of neuronal circuits. Our results of the thalamo-cortical pathway demonstrated significantly right larger than left $\mathrm{AD}, \mathrm{RD}$ and $\mathrm{ADC}$ in the girl group and in the combined group. The asymmetry in the boy group did not reach the significant level. The reported structural asymmetries are in line with previous findings showing that the correlation of WM with GA is more pronounced in the left hemisphere [75] and the lateralization of the somatosensory can be observed at birth [76]. The lateralization might be attributed to genetic programs during the prenatal stage, as asymmetry of gene expression in the human embryonic cortex has been found at gestational of 12 weeks [76].

The pattern of sexual dimorphisms in this period of brain development are generally different from those observed in later stages of brain development, suggesting that adult 
patterns of sexual dimorphism arise after birth and persist in adult brain development. Interestingly, there was no gender regional specificity in the selected gray matter structures, thalamus and thalamo-cortical pathways that can be identified with DTI. Sexual dimorphism has been observed in the neonatal brain after birth with males having $~ 9 \%$ larger intracranial volume than females, about $10 \%$ more cortical gray matter than females and $6 \%$ more cortical white matter [58]. In addition, previous fetal neonate studies have reported sexual dimorphism in head circumference as early as the second trimester [77]. The two sides and four-indices data analysis failed to demonstrate any sexual dimorphism in the selected structures.

\section{Conclusions}

This investigation showed that there is no significant boy-girl difference in the cytoarchitecture of the basal ganglia, thalamus and thalamo-cortical pathways. It is noteworthy to add that we measured different microstructural growth evidence of these structures among these structures in boys and girls. Subtle left-right asymmetric differences of these deep grey-matters have been observed within the first 3-4 weeks after birth. These are the results of genetic programming, but the neurodevelopment functioning might be affected by the social environment across the lifespan. Although this study has a limited number of subjects, we suggest that structural impairment of the thalamic asymmetry might be an objective marker of cognitive and motor functioning in children. Further investigations involving both larger sample size and multimodal imaging are required to confirm this suggestion. Our findings in mature neonate girls and boys set the ground truth data for future studies that associate neuro-behavior and subcortical sensory, motor and cognitive networks. Our study provides a useful baseline for future research toward detecting and characterizing a variety of pathological conditions as departures from expected growth trajectories.

Author Contributions: Conceptualization, M.M. and F.S.-M.; methodology, M.M., A.A.; software, F.S.-M.; validation, F.S.-M., M.F.; formal analysis, F.S.-M., M.F., A.A.; investigation, F.S.-M., M.M., A.A.; writing —original draft preparation, F.S.-M.; writing—review and editing, M.M., A.A., M.F., K.K.; supervision, M.M., A.A., K.K.; project administration, M.M. All authors have read and agreed to the published version of the manuscript.

Funding: This research received no external funding.

Institutional Review Board Statement: The study was conducted according to the guidelines of the Declaration of Helsinki, and approved by the Canton of Zurich ethics committee (protocol code StV 23/619/04 and StV-36/04; 2014).

Informed Consent Statement: Written informed consent was obtained from the parents or legal guardians of all subjects involved in the study.

Acknowledgments: We are grateful to Cornelia Hagmann, Neonatologist at the Universitats Kinderspital Zurich, Switzerland, for sharing the materials used for experiments.

Conflicts of Interest: The authors declare no conflict of interest.

\section{References}

1. Fama, R.; Sullivan, E.V. Thalamic structures and associated cognitive functions: Relations with age and aging. Neurosci. Biobehav. Rev. 2015, 54, 29-37. [CrossRef]

2. Steiner, H.; Tseng, K.Y. Handbook of Basal Ganglia Structure and Function; Academic Press: New York, NY, USA, 2010.

3. Ouyang, M.; Dubois, J.; Yu, Q.; Mukherjee, P.; Huang, H. Delineation of early brain development from fetuses to infants with diffusion MRI and beyond. NeuroImage 2019, 185, 836-850. [CrossRef]

4. Poh, J.S.; Li, Y.; Ratnarajah, N.; Fortier, M.V.; Chong, Y.-S.; Kwek, K.; Saw, S.-M.; Gluckman, P.D.; Meaney, M.J.; Qiu, A. Developmental synchrony of thalamocortical circuits in the neonatal brain. NeuroImage 2015, 116, 168-176. [CrossRef] [PubMed]

5. Qiu, A.; Mori, S.; Miller, M.I. Diffusion Tensor Imaging for Understanding Brain Development in Early Life. Annu. Rev. Psychol. 2015, 66, 853-876. [CrossRef]

6. Silbereis, J.C.; Pochareddy, S.; Zhu, Y.; Li, M.; Sestan, N. The Cellular and Molecular Landscapes of the Developing Human Central Nervous System. Neuron 2016, 89, 248-268. [CrossRef] 
7. Huttenlocher, P.R.; Dabholkar, A.S. Regional differences in synaptogenesis in human cerebral cortex. J. Comp. Neurol. 1997, 387, 167-178. [CrossRef]

8. Bystron, I.; Blakemore, C.; Rakic, P. Development of the human cerebral cortex: Boulder Committee revisited. Nat. Rev. Neurosci. 2008, 9, 110-122. [CrossRef] [PubMed]

9. Kostović, I.; Jovanov-Milosević, N. The development of cerebral connections during the first $20-45$ weeks 3 gestation. Semin. Fetal Neonatal. Med. 2006, 11, 415-422. [CrossRef]

10. Matsuzawa, J.; Matsui, M.; Konishi, T.; Noguchi, K.; Gur, R.C.; Bilker, W.; Miyawaki, T. Age-related volumetric changes of brain gray and white matter in healthy infants and children. Cereb. Cortex 2001, 11, 335-342. [CrossRef]

11. Holland, D.; Chang, L.; Ernst, T.M.; Curran, M.; Buchthal, S.D.; Alicata, D.; Skranes, J.; Johansen, H.; Hernandez, A.; Yamakawa, R.; et al. Structural Growth Trajectories and Rates of Change in the First 3 Months of Infant Brain Development. JAMA Neurol. 2014, 71, 1266-1274. [CrossRef] [PubMed]

12. Toulmin, H.; Beckmann, C.F.; O’Muircheartaigh, J.; Ball, G.; Nongena, P.; Makropoulos, A.; Ederies, A.; Counsell, S.J.; Kennea, N.; Arichi, T.; et al. Specialization and integration of functional thalamocortical connectivity in the human infant. Proc. Natl. Acad. Sci. USA 2015, 112, 6485-6490. [CrossRef]

13. Jones, E.G. The Thalamus, 2nd ed.; Cambridge University Press: Cambridge, UK, 2007.

14. Ceschin, R.; Wisnowski, J.L.; Paquette, L.B.; Nelson, M.D.; Blüml, S.; Panigrahy, A. Developmental synergy between thalamic structure and interhemispheric connectivity in the visual system of preterm infants. NeuroImage 2015, 8, 462-472. [CrossRef] [PubMed]

15. Kostovic, I.; Judas, M. The development of the subplate and thalamocortical connections in the human foetal brain. Acta Paediatr. 2010, 99, 1119-1127. [CrossRef] [PubMed]

16. Kostović, I.; Jovanov-Milošević, N.; Radoš, M.; Sedmak, G.; Benjak, V.; Kostović-Srzentić, M.; Vasung, L.; Čuljat, M.; Radoš, M.; Hüppi, P.; et al. Perinatal and early postnatal reorganization of the subplate and related cellular compartments in the human cerebral wall as revealed by histological and MRI approaches. Beiträge und Referate zur Anatomie und Entwickelungsgeschichte 2012, 219, 231-253. [CrossRef] [PubMed]

17. Volpe, J.J. Brain injury in premature infants: A complex amalgam of destructive and developmental disturbances. Lancet Neurol. 2009, 8, 110-124. [CrossRef]

18. Dean, J.M.; McClendon, E.; Hansen, K.; Azimi-Zonooz, A.; Chen, K.; Riddle, A.; Gong, X.; Sharifnia, E.; Hagen, M.; Ahmad, T.; et al. Prenatal cerebral ischemia disrupts MRI-defined cortical microstructure through disturbances in neuronal arborization. Sci. Transl. Med. 2013, 5, 168ra7. [CrossRef] [PubMed]

19. Molnár, Z.; Higashi, S.; López-Bendito, G. Choreography of early thalamocortical development. Cereb. Cortex 2003, 13, 661-669. [CrossRef] [PubMed]

20. Haber, S.N.; Calzavara, R. The cortico-basal ganglia integrative network: The role of the thalamus. Brain Res. Bull. 2009, 78, 69-74. [CrossRef] [PubMed]

21. Ball, G.; Srinivasan, L.; Aljabar, P.; Counsell, S.J.; Durighel, G.; Hajnal, J.V.; Rutherford, M.A.; Edwards, A.D. Development of cortical microstructure in the preterm human brain. Proc. Natl. Acad. Sci. USA 2013, 110, 9541-9546. [CrossRef]

22. Ball, G.; Boardman, J.P.; Aljabar, P.; Pandit, A.; Arichi, T.; Merchant, N.; Rueckert, D.; Edwards, A.D.; Counsell, S.J. The influence of preterm birth on the developing thalamocortical connectome. Cortex 2013, 49, 1711-1721. [CrossRef]

23. Ball, G.; Aljabar, P.; Zebari, S.; Tusor, N.; Arichi, T.; Merchant, N.; Robinson, E.C.; Ogundipe, E.; Rueckert, D.; Edwards, A.D.; et al. Rich-club organization of the newborn human brain. Proc. Natl. Acad. Sci. USA 2014, 111, 7456-7461. [CrossRef] [PubMed]

24. McQuillen, P.S.; Sheldon, R.A.; Shatz, C.J.; Ferriero, D.M. Selective Vulnerability of Subplate Neurons after Early Neonatal Hypoxia-Ischemia. J. Neurosci. 2003, 23, 3308-3315. [CrossRef]

25. Ligam, P.; Haynes, R.L.; Folkerth, R.D.; Liu, L.; Yang, M.; Volpe, J.J.; Kinney, H.C. Thalamic Damage in Periventricular Leukomalacia: Novel Pathologic Observations Relevant to Cognitive Deficits in Survivors of Prematurity. Pediatr. Res. 2009, 65, 524-529. [CrossRef] [PubMed]

26. Bechara, A.; Tranel, D.; Damasio, H. Characterization of the decision-making deficit of patients with ventromedial prefrontal cortex lesions. Brain 2000, 123, 2189-2202. [CrossRef]

27. Sonuga-Barke, E.J. Psychological heterogeneity in AD/HD-A dual pathway model of behaviour and cognition. Behav. Brain Res. 2002, 130, 29-36. [CrossRef]

28. Toplak, M.E.; Jain, U.; Tannock, R. Executive and motivational processes in adolescents with Attention-Deficit-Hyperactivity Disorder (ADHD). Behav. Brain Funct. 2005, 1, 10-1186. [CrossRef]

29. Joseph, R.M.; Tager-Flusberg, H. The relationship of theory of mind and executive functions to symptom type and severity in children with autism. Dev. Psychopathol. 2004, 16, 137-155. [CrossRef] [PubMed]

30. Robinson, S.; Goddard, L.; Dritschel, B.; Wisley, M.; Howlin, P. Executive functions in children with Autism Spectrum Disorders Brain Cogn. 2009, 71, 362-368. [CrossRef] [PubMed]

31. Clouchoux, C.; Kudelski, D.; Gholipour, A.; Warfield, S.K.; Viseur, S.; Bouyssi-Kobar, M.; Mari, J.-L.; Evans, A.C.; Du Plessis, A.J.; Limperopoulos, C. Quantitative in vivo MRI measurement of cortical development in the fetus. Beiträge und Referate zur Anatomie und Entwickelungsgeschichte 2011, 217, 127-139. [CrossRef]

32. Andescavage, N.N.; du Plessis, A.; McCarter, R.; Serag, A.; Evangelou, I.; Vezina, G.; Robertson, R.; Limperopoulos, C. Complex trajectories of brain development in the healthy human fetus. Cereb. Cortex 2017, 27, 5274-5283. [CrossRef] 
33. McKinstry, R.C.; Mathur, A.; Miller, J.H.; Ozcan, A.; Snyder, A.Z.; Schefft, G.L.; Almli, C.R.; Shiran, S.I.; Conturo, T.E.; Neil, J.J. Radial Organization of Developing Preterm Human Cerebral Cortex Revealed by Non-invasive Water Diffusion Anisotropy MRI. Cereb. Cortex 2002, 12, 1237-1243. [CrossRef]

34. Mrzljak, L.; Uylings, H.B.M.; Kostovic, I.; Van Eden, C.G. Prenatal development of neurons in the human prefrontal cortex: I. A qualitative Golgi study. J. Comp. Neurol. 1988, 271, 355-386. [CrossRef]

35. Levman, J.; MacDonald, P.; Lim, A.R.; Forgeron, C.; Takahashi, E. A pediatric structural MRI analysis of healthy brain development from newborns to young adults. Hum. Brain Mapp. 2017, 38, 5931-5942. [CrossRef]

36. Cantalupo, C.; Hopkins, W.D. Asymmetric Broca's area in great apes. Nat. Cell Biol. 2001, 414, 505. [CrossRef] [PubMed]

37. Amunts, K.; Schlaug, G.; Schleicher, A.; Steinmetz, H.; Dabringhaus, A.; Roland, P.E.; Zilles, K. Asymmetry in the human motor cortex and handedness. Neuroimage 1996, 4, 216-222. [CrossRef]

38. Amunts, K.; Armstrong, E.; Malikovic, A.; Hömke, L.; Mohlberg, H.; Schleicher, A.; Zilles, K. Gender-Specific Left-Right Asymmetries in Human Visual Cortex. J. Neurosci. 2007, 27, 1356-1364. [CrossRef] [PubMed]

39. Good, C.D.; Johnsrude, I.; Ashburner, J.; Henson, R.N.; Friston, K.J.; Frackowiak, R.S. Cerebral asymmetry and the effects of sex and handedness on brain structure: A voxel-based morphometric analysis of 465 normal adult human brains. Neuroimage 2001, 14, 685-700. [CrossRef] [PubMed]

40. Watkins, K.E.; Paus, T.; Lerch, J.; Zijdenbos, A.; Collins, D.; Neelin, P.; Taylor, J.; Worsley, K.; Evans, A. Structural Asymmetries in the Human Brain: A Voxel-based Statistical Analysis of 142 MRI Scans. Cereb. Cortex 2001, 11, 868-877. [CrossRef]

41. Stiles, J.; Jernigan, T.L. The Basics of Brain Development. Neuropsychol. Rev. 2010, 20, 327-348. [CrossRef] [PubMed]

42. Pineda, R.G.; Tjoeng, T.H.; Vavasseur, C.; Kidokoro, H.; Neil, J.J.; Inder, T. Patterns of Altered Neurobehavior in Preterm Infants within the Neonatal Intensive Care Unit. J. Pediatr. 2013, 162, 470-476.e1. [CrossRef]

43. Pineda, R.G.; Neil, J.; Dierker, D.; Smyser, C.D.; Wallendorf, M.; Kidokoro, H.; Reynolds, L.C.; Walker, S.; Rogers, C.; Mathur, A.M.; et al. Alterations in Brain Structure and Neurodevelopmental Outcome in Preterm Infants Hospitalized in Different Neonatal Intensive Care Unit Environments. J. Pediatr. 2014, 164, 52-60.e2. [CrossRef]

44. Saadani-Makki, F.; Hagmann, C.; Balédent, O.; Makki, M.I. Early assessment of lateralization and sex influences on the microstructure of the white matter corticospinal tract in healthy term neonates. J. Neurosci. Res. 2019, 97, 480-491. [CrossRef] [PubMed]

45. Lebel, C.; Walker, L.; Leemans, A.; Phillips, L.; Beaulieu, C. Microstructural maturation of the human brain from childhood to adulthood. NeuroImage 2008, 40, 1044-1055. [CrossRef] [PubMed]

46. Dubois, J.; Dehaene-Lambertz, G.; Kulikova, S.; Poupon, C.; Hüppi, P.S.; Hertz-Pannier, L. The early development of brain white matter: A review of imaging studies in fetuses, newborns and infants. Neuroscience 2014, 276, 48-71. [CrossRef] [PubMed]

47. Rose, J.; Cahill-Rowley, K.; Vassar, R.; Yeom, K.W.; Stecher, X.; Stevenson, D.K.; Hintz, S.R.; Barnea-Goraly, N. Neonatal brain microstructure correlates of neurodevelopment and gait in preterm children 18-22 mo of age: An MRI and DTI study. Pediatr. Res. 2015, 78, 700-708. [CrossRef] [PubMed]

48. Ratnarajah, N.; Rifkin-Graboi, A.; Fortier, M.V.; Chong, Y.S.; Kwek, K.; Saw, S.-M.; Godfrey, K.M.; Gluckman, P.D.; Meaney, M.J.; Qiu, A. Structural connectivity asymmetry in the neonatal brain. NeuroImage 2013, 75, 187-194. [CrossRef]

49. Hendren, R.L.; De Backer, I.; Pandina, G.J. Review of neuroimaging studies of child and adolescent psychiatric disorders from the past 10 years. J. Am. Acad. Child Adolesc. Psychiatry 2000, 39, 815-828. [CrossRef]

50. Oertel-Knöchel, V.; Linden, D.E.J. Cerebral Asymmetry in Schizophrenia. Neuroscientist 2011, 17, 456-467. [CrossRef]

51. Herbert, M.R.; Ziegler, D.A.; Deutsch, C.K.; O’Brien, L.M.; Kennedy, D.N.; Filipek, P.A.; Bakardjiev, A.I.; Hodgson, J.; Takeoka, M.; Makris, N.; et al. Brain asymmetries in autism and developmental language disorder: A nested whole-brain analysis. Brain 2004, 128, 213-226. [CrossRef]

52. Makki, M.I.; Behen, M.; Bhatt, A.; Wilson, B.; Chugani, H.T. Microstructural abnormalities of striatum and thalamus in children with Tourette syndrome. Mov. Disord. Off. J. Mov. Disord. Soc. 2008, 23, 2349-2356. [CrossRef]

53. Alkonyi, B.; Chugani, H.T.; Behen, M.; Halverson, S.; Helder, E.; Makki, M.I.; Juhász, C. The role of the thalamus in neuro-cognitive dysfunction in early unilateral hemispheric injury: A multimodality imaging study of children with Sturge-Weber syndrome. Eur. J. Paediatr. Neurol. 2010, 14, 425-433. [CrossRef] [PubMed]

54. Sun, T.; Walsh, C.A. Molecular approaches to brain asymmetry and handedness. Nat. Rev. Neurosci. 2006, 7, 655-662. [CrossRef] [PubMed]

55. Bishop, D.V.M. Cerebral Asymmetry and Language Development: Cause, Correlate, or Consequence? Science 2013, 340,1230531 [CrossRef]

56. Khan, S.; Vasung, L.; Marami, B.; Rollins, C.K.; Afacan, O.; Ortinau, C.M.; Yang, E.; Warfield, S.K.; Gholipour, A. Fetal brain growth portrayed by a spatiotemporal diffusion tensor MRI atlas computed from in utero images. NeuroImage 2019, 185, 593-608. [CrossRef] [PubMed]

57. Hering-Hanit, R.; Achiron, R.; Lipitz, S.; Achiron, A. Asymmetry of fetal cerebral hemispheres: In utero ultrasound study. Arch. Dis. Child. Fetal Neonatal Ed. 2001, 85, F194-F196. [CrossRef]

58. Gilmore, J.H.; Lin, W.; Prastawa, M.W.; Looney, C.B.; Vetsa, Y.S.K.; Knickmeyer, R.C.; Evans, D.D.; Smith, J.K.; Hamer, R.M.; Lieberman, J.A.; et al. Regional Gray Matter Growth, Sexual Dimorphism, and Cerebral Asymmetry in the Neonatal Brain. J. Neurosci. 2007, 27, 1255-1260. [CrossRef] [PubMed] 
59. Li, M.; Chen, H.; Wang, J.; Liu, F.; Long, Z.; Wang, Y.; Iturria-Medina, Y.; Zhang, J.; Yu, C.; Chen, H. Handedness- and HemisphereRelated Differences in Small-World Brain Networks: A Diffusion Tensor Imaging Tractography Study. Brian Connect. Amr. 2014, 1, 145-156. [CrossRef] [PubMed]

60. Puetz, V.B.; Parker, D.; Kohn, N.; Dahmen, B.; Verma, R.; Konrad, K. Altered brain network integrity after childhood maltreatment: A structural connectomic DTI-study. Hum. Brain Mapp. 2017, 38, 855-868. [CrossRef]

61. Mannerkoski, M.K.; Heiskala, H.J.; Van Leemput, K.; Åberg, L.E.; Raininko, R.; Hämäläinen, J.; Autti, T.H.; Aring, E.L. Subjects With Intellectual Disability and Familial Need for Full-Time Special Education Show Regional Brain Alterations: A Voxel-Based Morphometry Study. Pediatr. Res. 2009, 66, 306-311. [CrossRef] [PubMed]

62. Bültmann, E.; Spineli, L.M.; Hartmann, H.; Lanfermann, H. Measuring in vivo cerebral maturation using age-related T2 relaxation times at 3 T. Brain Dev. 2018, 40, 85-93. [CrossRef] [PubMed]

63. Draganski, B.; Kherif, F.; Klöppel, S.; Cook, P.A.; Alexander, D.C.; Parker, G.J.M.; Deichmann, R.; Ashburner, J.; Frackowiak, R.S.J. Evidence for Segregated and Integrative Connectivity Patterns in the Human Basal Ganglia. J. Neurosci. 2008, 28, 7143-7152. [CrossRef]

64. Metzger, C.D.; van der Werf, Y.D.; Walter, M. Functional mapping of thalamic nuclei and their integration into cortico-striatalthalamo-cortical loops via ultra-high resolution imaging-from animal anatomy to in vivo imaging in humans. Front. Neurosci. 2013, 7, 24. [CrossRef] [PubMed]

65. Shi, J.; Wang, Y.; Ceschin, R.; An, X.; Lao, Y.; Vanderbilt, D.; Nelson, M.D.; Thompson, P.M.; Panigrahy, A.; Leporé, N. A Multivariate Surface-Based Analysis of the Putamen in Premature Newborns: Regional Differences within the Ventral Striatum. PLoS ONE 2013, 8, e66736. [CrossRef] [PubMed]

66. Lao, Y.; Nguyen, B.; Tsao, S.; Gajawelli, N.; Law, M.; Chui, H.; Weiner, M.; Wang, Y.; Leporé, N. A T1 and DTI fused 3D corpus callosum analysis in MCI subjects with high and low cardiovascular risk profile. NeuroImage 2017, 14, 298-307. [CrossRef]

67. Dennison, M.; Whittle, S.; Yücel, M.; Vijayakumar, N.; Kline, A.; Simmons, J.G.; Allen, N.B. Mapping subcortical brain maturation during adolescence: Evidence of hemisphere- and sex-specific longitudinal changes. Dev. Sci. 2013, 16, 772-791. [CrossRef]

68. Koolschijn, P.C.M.; Crone, E.A. Sex differences and structural brain maturation from childhood to early adulthood. Dev. Cogn. Neurosci. 2013, 5, 106-118. [CrossRef] [PubMed]

69. Guderian, S.; Dzieciol, A.M.; Gadian, D.G.; Jentschke, S.; Doeller, C.F.; Burgess, N.; Mishkin, M.; Vargha-Khadem, F. Hippocampal Volume Reduction in Humans Predicts Impaired Allocentric Spatial Memory in Virtual-Reality Navigation. J. Neurosci. 2015, 35, 14123-14131. [CrossRef]

70. Dzieciol, A.M.; Bachevalier, J.; Saleem, K.S.; Gadian, D.G.; Saunders, R.; Chong, W.K.; Banks, T.; Mishkin, M.; Vargha-Khadem, F. Hippocampal and diencephalic pathology in developmental amnesia. Cortex 2017, 86, 33-44. [CrossRef]

71. Geva, S.; Jentschke, S.; Argyropoulos, G.P.; Chong, W.; Gadian, D.G.; Vargha-Khadem, F. Volume reduction of caudate nucleus is associated with movement coordination deficits in patients with hippocampal atrophy due to perinatal hypoxia-ischaemia. NeuroImage 2020, 28, 102429. [CrossRef]

72. Alcauter, S.; Lin, W.; Smith, J.K.; Short, S.J.; Goldman, B.D.; Reznick, J.S.; Gilmore, J.H.; Gao, W. Development of Thalamocortical Connectivity during Infancy and Its Cognitive Correlations. J. Neurosci. 2014, 34, 9067-9075. [CrossRef]

73. Ball, G.; Pazderova, L.; Chew, A.; Tusor, N.; Merchant, N.; Arichi, T.; Allsop, J.M.; Cowan, F.M.; Edwards, A.D.; Counsell, S.J. Thalamocortical Connectivity Predicts Cognition in Children Born Preterm. Cereb. Cortex 2015, 25, 4310-4318. [CrossRef] [PubMed]

74. Željka, K.; Majić, V.; Vasung, L.; Huang, H.; Kostović, I. Growth of Thalamocortical Fibers to the Somatosensory Cortex in the Human Fetal Brain. Front. Neurosci. 2017, 11, 233. [CrossRef] [PubMed]

75. Jin, C.; Li, Y.; Li, X.; Liu, C.; Wang, M.; Cheng, Y.; Zheng, J.; Yang, J. Associations of gestational age and birth anthropometric indicators with brain white matter maturation in ful-term neonates. Hum. Brain Mapp. 2019, 40, 3620-3630. [PubMed]

76. Erberich, S.G.; Panigrahy, A.; Friedlich, P.; Seri, I.; Nelson, M.D.; Gilles, F. Somatosensory lateralization in the newborn brain. NeuroImage 2006, 29, 155-161. [CrossRef] [PubMed]

77. Grantz, K.L.; Hediger, M.L.; Liu, D.; Louis, G.M.B. Fetal growth standards: The NICHD fetal growth study approach in context with INTERGROWTH-21st and the World Health Organization Multicentre Growth Reference Study. Am. J. Obstet. Gynecol. 2018, 218, S641-S655. [CrossRef] 